\title{
Lone-Pair Hole on P: P...N Pnicogen Bonds Assisted by Halogen Bonds
}

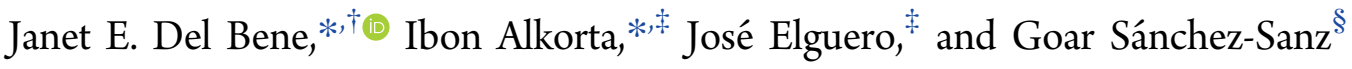 \\ ${ }^{\dagger}$ Department of Chemistry, Youngstown State University, Youngstown, Ohio 44555, United States \\ ${ }^{\ddagger}$ Instituto de Química Médica (IQM-CSIC), Juan de la Cierva, 3, E-28006 Madrid, Spain \\ ${ }^{\S}$ Irish Centre of High-End Computing (ICHEC), Grand Canal Quay, Dublin 2 D02 HP83, Ireland
}

Supporting Information

ABSTRACT: Ab initio MP2/aug'-cc-pVTZ calculations have been performed on the binary complexes $\mathrm{XY}: \mathrm{PH}_{3}$ for $\mathrm{XY}=\mathrm{ClCl}, \mathrm{FCl}$, and $\mathrm{FBr}$; and $\mathrm{PH}_{3}: \mathrm{N}$-base for $\mathrm{N}$-base $=\mathrm{NCH}, \mathrm{NH}_{3}, \mathrm{NCF}, \mathrm{NCCN}$, and $\mathrm{N}_{2}$; and the corresponding ternary complexes $\mathrm{XY}: \mathrm{PH}_{3}: \mathrm{N}$-base, to investigate $\mathrm{P} \cdots \mathrm{N}$ pnicogen bond formation through the lone-pair hole at $\mathrm{P}$ in the binary complexes and $\mathrm{P} \cdots \mathrm{N}$ pnicogen-bond formation assisted by $\mathrm{P} \cdots \mathrm{Y}$ halogen bond formation through the $\sigma$-hole at Y. Although the binary complexes $\mathrm{PH}_{3}: \mathrm{N}$-base that form through the lone-pair hole have very small binding energies, they are not equilibrium structures on their potential surfaces. The presence of the P...Y halogen bond makes $\mathrm{PH}_{3}$ a better electron-pair acceptor through its lone-pair hole, leading to stable ternary complexes $\mathrm{XY}: \mathrm{PH}_{3}: \mathrm{N}$-base. The halogen bonds in $\mathrm{ClCl}: \mathrm{PH}_{3}$ and $\mathrm{ClCl}: \mathrm{PH}_{3}: \mathrm{NCCN}$ are traditional halogen bonds, but in the remaining binary and ternary complexes, they are chlorine- or bromine-shared halogen bonds. For a given nitrogen base, the $\mathrm{P} \cdots \mathrm{N}$ pnicogen bond in the ternary complex $\mathrm{FCl}: \mathrm{PH}_{3}: \mathrm{N}$-base appears to be stronger than that bond in $\mathrm{FBr}: \mathrm{PH}_{3}: \mathrm{N}$-base, which is stronger than the $\mathrm{P} \cdots \mathrm{N}$ bond in the corresponding $\mathrm{ClCl}: \mathrm{PH}_{3}: \mathrm{N}$-base complex. EOM-CCSD spin-spin coupling constants for the binary and ternary complexes with $\mathrm{ClCl}$ and $\mathrm{FCl}$ are also consistent with the changing nature of the halogen bonds in these complexes. At long $\mathrm{P}-\mathrm{Cl}$ distances, the coupling constant ${ }^{1 \mathrm{x}} \mathrm{J}(\mathrm{P}-\mathrm{Cl})$ increases with decreasing distance but then decreases as the $\mathrm{P}-\mathrm{Cl}$ distance continues to decrease, and the halogen bonds become chlorine-shared bonds. At the shorter distances, ${ }^{1 \mathrm{x}} J(\mathrm{P}-\mathrm{Cl})$ approaches the value of ${ }^{1} \mathrm{~J}(\mathrm{P}-\mathrm{Cl})$ for the cation ${ }^{+}\left(\mathrm{Cl}-\mathrm{PH}_{3}\right)$. The coupling constants ${ }^{1 \mathrm{p}} \mathrm{J}(\mathrm{P}-\mathrm{N})$ are small and, with one exception, are greater in $\mathrm{ClCl}: \mathrm{PH}_{3}: \mathrm{N}$-base complexes compared to that in $\mathrm{FCl}: \mathrm{PH}_{3}: \mathrm{N}$-base, despite the shorter $\mathrm{P}-\mathrm{N}$ distances in the latter.

\section{INTRODUCTION}

The concept of the $\sigma$-hole proposed by Politzer and co-workers has provided insight into the formation of halogen bonds, in which a halogen atom acts as a Lewis acid as it accepts a pair of electrons from a Lewis base. ${ }^{1-3}$ This $\sigma$-hole concept has been extended to complexes formed with atoms across the Periodic $\mathrm{Table}^{4,5}$ in which the atom acts as a Lewis acid. Chalcogen bonds are those involving Group 16 atoms, ${ }^{6-9}$ pnicogen bonds form with Group 15 atoms, ${ }^{10-12}$ and tetrel bonds involve atoms from Group 14. ${ }^{13-15}$ The $\sigma$-hole of an atom corresponds to a positive region of the molecular electrostatic potential (MEP), which is found on the opposite side of a covalent bond formed by that atom. $\pi$-Holes ${ }^{16,17}$ may also exist, which correspond to positive regions of the MEP above and below the $\sigma$ plane of a molecule. $\pi$-Holes have been found in molecules such as $\mathrm{NO}_{2} \mathrm{R}^{18-24} \mathrm{PO}_{2} \mathrm{R},{ }^{25}$ and $\mathrm{CO}_{2}{ }^{26}$

In 2011, while investigating complexes of $\mathrm{NF}_{3}$ with a variety of electron donors, we found a local minimum in the MEP at $\mathrm{N}$ directly opposite the lone pair and called this a lone-pair hole. ${ }^{27}$ Lone-pair holes were also found for $\mathrm{PX}_{3}$ molecules with $\mathrm{X}=\mathrm{F}$, $\mathrm{Cl}$, and $\mathrm{Br}$, and these were used to form pnicogen bonds in complexes $\mathrm{PX}_{3}: \mathrm{NCH}$ and $\mathrm{PX}_{3}: \mathrm{NH}_{3}{ }^{28}$ Frontera and co-workers have recently investigated lone-pair holes in complexes with $\mathrm{ZF}_{3}$, for $\mathrm{Z}=\mathrm{N}, \mathrm{P}, \mathrm{As}$, and $\mathrm{Sb}^{29}$ All of the lone-pair holes identified thus far have been found in trihalogenated pnicogen derivatives.

In a previous 2014 paper, we explored the formation of traditional and chlorine-shared halogen bonds in complexes $\mathrm{H}_{2} \mathrm{XP}: \mathrm{ClCl}$ and $\mathrm{H}_{2} \mathrm{XP}: \mathrm{ClF}$, for $\mathrm{X}=\mathrm{F}, \mathrm{Cl}, \mathrm{OH}, \mathrm{NC}, \mathrm{CN}, \mathrm{CCH}$, $\mathrm{CH}_{3}$, and $\mathrm{H}^{30}$ This study led us to ask whether or not the presence of a halogen bond would favor the formation of a pnicogen bond through the lone-pair hole on $\mathrm{P}$ in complexes involving $\mathrm{PH}_{3}$. To answer this question, we have investigated the binary complexes $\mathrm{XY}: \mathrm{PH}_{3}$ for $\mathrm{XY}=\mathrm{ClCl}, \mathrm{FCl}$, and $\mathrm{FBr}$; and $\mathrm{PH}_{3}$ :N-base for N-base $=\mathrm{NCH}, \mathrm{NH}_{3}, \mathrm{NCF}, \mathrm{NCCN}$, and $\mathrm{N}_{2}$; and the corresponding ternary complexes $\mathrm{XY}: \mathrm{PH}_{3}: \mathrm{N}$-base, which are depicted in Scheme 1. In the present paper, we report and discuss the structures, binding energies, nonadditivities of binding energies, electron density properties, and Wiberg bond indexes of these binary and ternary complexes, as well as the

Received: December 13, 2016

Revised: January 17, 2017

Published: February 3, 2017 
Scheme 1. Schematic Representation of the Ternary Complexes $\mathrm{XY}: \mathrm{PH}_{3}: \mathrm{N}$-base

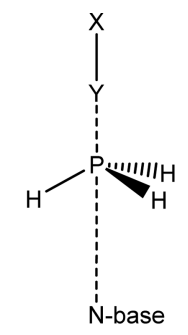

$\mathrm{XY}=\mathrm{ClCl}, \mathrm{FCl}, \mathrm{FBr}$

EOM-CCSD spin-spin coupling constants ${ }^{1 x} J(\mathrm{P}-\mathrm{Cl})$ and ${ }^{1 \mathrm{p}} J(\mathrm{P}-\mathrm{N})$ across halogen and pnicogen bonds, respectively, in binary and ternary complexes with $\mathrm{ClCl}$ and $\mathrm{FCl}$.

\section{METHODS}

The structures of the isolated monomers $\mathrm{PH}_{3} ; \mathrm{XY}$, for $\mathrm{XY}=$ $\mathrm{ClCl}, \mathrm{FCl}$, and $\mathrm{FBr}$; and the nitrogen bases $\mathrm{NCH}, \mathrm{NH}_{3}, \mathrm{NCF}$, $\mathrm{NCCN}$, and $\mathrm{N}_{2}$; the binary complexes $\mathrm{XY}: \mathrm{PH}_{3}$ and $\mathrm{PH}_{3}: \mathrm{N}$ base; and the ternary complexes $\mathrm{XY}: \mathrm{PH}_{3}: \mathrm{N}$-base were optimized at second-order Møller-Plesset perturbation theory $(\mathrm{MP2})^{31-34}$ with the aug'-cc-pVTZ basis set. ${ }^{35}$ This basis set was derived from the Dunning aug-cc-pVTZ basis set ${ }^{36,37}$ by removing diffuse functions from $\mathrm{H}$ atoms. Frequencies were computed to confirm that these optimized structures correspond to equilibrium structures on their potential surfaces. Optimization and frequency calculations were performed using the Gaussian 09 program. ${ }^{38}$ Binding energies of binary and ternary complexes were defined as $-\Delta E$ for the reaction that forms a complex from the corresponding isolated monomers. Nonadditivities of binding energies $(\delta \Delta E)$ of ternary complexes were evaluated as the reaction energy $(\Delta E)$ for the formation of the ternary complex from the corresponding monomers, minus the sum of the reaction energies for the formation of the corresponding binary complexes from the corresponding monomers.

The electron densities of complexes have been analyzed using the Atoms in Molecules (AIM) methodology ${ }^{39-42}$ employing the AIMAll ${ }^{43}$ program. Topological analysis of the electron density produces a molecular graph of each complex. This graph identifies the location of electron density features of interest, including the electron density $(\rho)$ maxima associated with the various nuclei and saddle points that correspond to bond critical points (BCPs). The zero gradient line that connects a $\mathrm{BCP}$ with two nuclei is the bond path. The electron density at an intermolecular BCP $\left(\rho_{\mathrm{BCP}}\right)$, the Laplacian $\left(\nabla^{2} \rho_{\mathrm{BCP}}\right)$ at that point, and the total energy density $\left(H_{\mathrm{BCP}}\right)$ have also been evaluated. Wiberg bond indexes ${ }^{44}$ have also been computed for the $\mathrm{X}-\mathrm{Y}$ bonds and the $\mathrm{P} \cdots \mathrm{Y}$ halogen and $\mathrm{P} \cdots \mathrm{N}$ pnicogen intermolecular bonds in these complexes.

Coupling constants for binary $\mathrm{ClCl}: \mathrm{PH}_{3}$ and $\mathrm{FCl}: \mathrm{PH}_{3}$ complexes and ternary $\mathrm{ClCl}: \mathrm{PH}_{3}: \mathrm{N}$-base and $\mathrm{FCl}: \mathrm{PH}_{3}: \mathrm{N}$-base complexes and the ion ${ }^{+}\left(\mathrm{Cl}-\mathrm{PH}_{3}\right)$ were evaluated using the equation-of-motion coupled cluster singles and doubles (EOMCCSD) method in the CI (configuration interaction)-like approximation, ${ }^{45,46}$ with all electrons correlated. For these calculations, the Ahlrichs ${ }^{47}$ qzp basis set was placed on ${ }^{13} \mathrm{C}$, ${ }^{15} \mathrm{~N}$, and ${ }^{19} \mathrm{~F}$, and the qz2p basis set was placed on ${ }^{31} \mathrm{P}$ and ${ }^{35} \mathrm{Cl}$. The Dunning cc-pVDZ basis set was used for ${ }^{1} \mathrm{H}$ atoms.
Coupling constants were obtained as the sum of the paramagnetic spin orbit (PSO), diamagnetic spin orbit (DSO), Fermi contact (FC), and spin dipole (SD) terms. The EOM-CCSD calculations were performed using ACES $\mathrm{II}^{48}$ on the HPC cluster Oakley at the Ohio Supercomputer Center.

\section{RESULTS AND DISCUSSION}

Lone-Pair Hole of $\mathrm{PH}_{3}$. The MEP on the 0.001 au electron density isosurface of $\mathrm{PH}_{3}$ is illustrated in Figure 1. The white

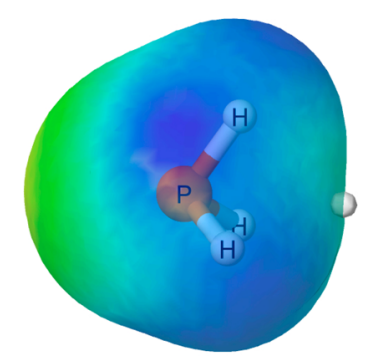

Figure 1. MEP on the 0.001 au electron density isosurface of $\mathrm{PH}_{3}$. The color scheme is yellow < green $<$ aqua $<$ blue, with electron densities from -0.02 to $+0.02 \mathrm{au}$. The white dot represents the location of the minimum.

dot on the surface represents a negative local minimum at the lone-pair hole, with a value of -0.002 au. The negative value of the MEP indicates that this region may not be suitable to act as an electron acceptor. However, this situation could change if the $\mathrm{PH}_{3}$ molecule were polarized.

Binary Complexes. The structures, total energies, and molecular graphs of the binary complexes $\mathrm{PH}_{3}: \mathrm{N}$-base, for $\mathrm{N}$ base $=\mathrm{NCH}, \mathrm{NH}_{3}, \mathrm{NCF}, \mathrm{NCCN}$, and $\mathrm{N}_{2}$, are reported in Table S1 of the Supporting Information, and their binding energies and $\mathrm{P}-\mathrm{N}$ distances are given in Table 1. Figure 2a

Table 1. Binding Energies $\left(-\Delta E, \mathrm{~kJ} \cdot \mathrm{mol}^{-1}\right)$ and $\mathrm{P}-\mathrm{N}$ and $\mathrm{P}-\mathrm{Y}$ Distances $(\mathrm{R}, \AA)$ in Binary Complexes $\mathrm{PH}_{3}$ :N-base and $\mathrm{XY}: \mathrm{PH}_{3}$

\begin{tabular}{lccccccc}
\multicolumn{3}{c}{$\mathrm{PH}_{3}: \mathrm{N}$-base } & & & \multicolumn{3}{c}{$\mathrm{XY}^{a} \mathrm{PH}_{3}{ }^{b}$} \\
\cline { 1 - 2 } \cline { 5 - 7 } N-base $=$ & $-\Delta E$ & $R(\mathrm{P}-\mathrm{N})$ & & $\mathrm{XY}=$ & $-\Delta E$ & $R(\mathrm{P}-\mathrm{Y})$ \\
$\mathrm{NCH}$ & 2.3 & 4.000 & & $\mathrm{ClCl}$ & $14.3^{c}$ & 3.048 \\
$\mathrm{NH}_{3}$ & 1.3 & 4.340 & & $\mathrm{FCl}$ & $51.2^{c}$ & 2.182 \\
$\mathrm{NCF}$ & 2.5 & 3.970 & & $\mathrm{FBr}$ & 65.0 & 2.391 \\
$\mathrm{NCCN}$ & 2.4 & 3.998 & & & & \\
$\mathrm{~N}_{2}$ & 1.6 & 4.109 & & & &
\end{tabular}

${ }^{a}$ These binary complexes with $C_{3 v}$ symmetry are not equilibrium structures on their potential surfaces because they have two imaginary frequencies. ${ }^{b}$ These binary complexes are equilibrium structures with $C_{3 v}$ symmetry. ${ }^{c}$ Taken from ref 30 .

presents the structure of $\mathrm{PH}_{3}: \mathrm{NH}_{3}$, which shows that the $\mathrm{NH}_{3}$ molecule is oriented for electron donation to $\mathrm{PH}_{3}$ through its lone-pair hole. The binding energies of these binary complexes are very small, ranging between 1 and $3 \mathrm{~kJ} \cdot \mathrm{mol}^{-1}$ at $\mathrm{P}-\mathrm{N}$ distances of about $4 \AA$, which are long for $\mathrm{P} \cdots \mathrm{N}$ pnicogen bonds. Although these are bound complexes, they have two degenerate imaginary frequencies, which indicate that they are not equilibrium structures on their potential surfaces. Following these frequencies eventually leads to equilibrium complexes $\mathrm{H}_{3} \mathrm{P}$ :N-base with $\mathrm{P} \cdots \mathrm{N}$ pnicogen bonds formed through the $\sigma$ hole on $\mathrm{P} .{ }^{10,49}$ The $\mathrm{H}_{3} \mathrm{P}: \mathrm{NH}_{3}$ complex with a pnicogen bond 


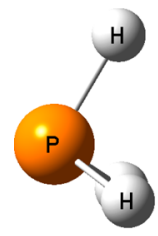

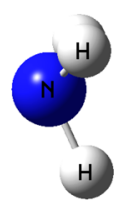

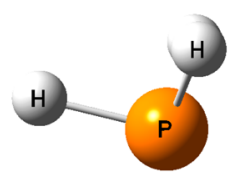

b

Figure 2. Pnicogen-bonded complexes between $\mathrm{PH}_{3}$ and $\mathrm{NH}_{3}$. Structure a illustrates bond formation through the $\mathrm{P}$ lone-pair hole, while $\mathbf{b}$ illustrates bond formation through the P $\sigma$-hole.

formed through the $\mathrm{P} \sigma$-hole is illustrated in Figure $2 \mathrm{~b}$. It has a binding energy of $7.8 \mathrm{~kJ} \cdot \mathrm{mol}^{-1}$ at a $\mathrm{P}-\mathrm{N}$ distance of $3.292 \AA$.

Topological analyses of the electron density show a unique bond path connecting the $\mathrm{P}$ atom of $\mathrm{PH}_{3}$ with $\mathrm{N}$ of the $\mathrm{N}$-base in each complex, as can be seen in Table S1. The weak nature of these bonds is confirmed by the small values of the electron density at the P-N BCPs, which are 0.002 or 0.003 au. Such values are characteristic of weak van der Waals contacts, which ideally have a value smaller than 0.002 au. $^{50}$

The structures, total energies, and molecular graphs of the binary complexes $\mathrm{XY}: \mathrm{PH}_{3}$, for $\mathrm{XY}=\mathrm{ClCl}, \mathrm{FCl}$, and $\mathrm{FBr}$, are reported in Table S2. Table 1 also presents their binding energies and $\mathrm{P}-\mathrm{Y}$ distances. These complexes are stabilized by $\mathrm{P} \cdots \mathrm{Cl}$ or $\mathrm{P} \cdots \mathrm{Br}$ halogen bonds. Their binding energies vary from 14 to $65 \mathrm{~kJ} \cdot \mathrm{mol}^{-1}$ and decrease with respect to $\mathrm{XY}$ in the order

\section{$\mathrm{FBr}>\mathrm{FCl}>\mathrm{ClCl}$}

as the difference between the electronegativities of the atoms $\mathrm{X}$ and $\mathrm{Y}$ decreases. The $\mathrm{P}-\mathrm{Y}$ distances are determined by two factors: the strengths of the halogen bonds in these complexes, and the radii of the $\mathrm{Cl}$ and $\mathrm{Br}$ atoms. These complexes have $C_{3 v}$ symmetry and are equilibrium structures on their potential surfaces with no imaginary frequencies.

The MEPs of these complexes have critical points on the 0.001 au electron density isosurfaces with electron density values of $+0.052,+0.061$, and +0.008 au for $\mathrm{FBr}: \mathrm{PH}_{3}, \mathrm{FCl}: \mathrm{PH}_{3}$, and $\mathrm{ClCl}: \mathrm{PH}_{3}$, respectively. These points are found at maxima on the $\mathrm{FBr}: \mathrm{PH}_{3}$ and $\mathrm{FCl}: \mathrm{PH}_{3}$ surfaces and at a minimum on the $\mathrm{ClCl}: \mathrm{PH}_{3}$ surface. The MEP of $\mathrm{FCl}: \mathrm{PH}_{3}$ is illustrated in Figure 3. The black dot shown on the MEP corresponds to the lone-pair hole.

Ternary Complexes. As noted above, although the binary complexes $\mathrm{PH}_{3}: \mathrm{N}$-base are bound, they are not equilibrium structures on their potential surfaces. Can these complexes be stabilized by the presence of a P...Y halogen bond in ternary

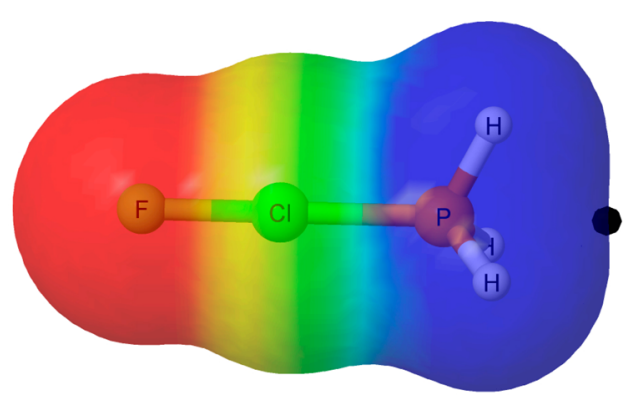

Figure 3. MEP on the 0.001 au electron density isosurface of $\mathrm{FCl}: \mathrm{PH}_{3}$. The color scheme is red $<$ yellow $<$ green $<$ aqua $<$ blue, with values from -0.05 to $+0.05 \mathrm{au}$. The location of the lone-pair hole is indicated with a black dot and has a value of +0.061 au. complexes $\mathrm{XY}: \mathrm{PH}_{3}: \mathrm{N}$-base? If so, what are the properties of these complexes? To answer these questions, we present and discuss the ternary complexes $\mathrm{ClCl}: \mathrm{PH}_{3}: \mathrm{N}-$ base, $\mathrm{FCl}: \mathrm{PH}_{3}: \mathrm{N}$ base, and $\mathrm{FBr}: \mathrm{PH}_{3}: \mathrm{N}$-base, in that order.

$\mathrm{ClCl}: \mathrm{PH}_{3}: \mathrm{N}$-base Ternary Complexes. Table S3 presents the structures, total energies, and molecular graphs of the complexes $\mathrm{ClCl}: \mathrm{PH}_{3}: \mathrm{N}$-base. Table 2 reports their binding energies, the nonadditivities of the binding energies, and $\mathrm{P}-\mathrm{Cl}$, $\mathrm{P}-\mathrm{N}$, and $\mathrm{Cl}-\mathrm{Cl}$ distances. All of the ternary complexes are equilibrium structures on their potential surfaces. Missing from Table 2 is the complex ClCl: $\mathrm{PH}_{3}: \mathrm{N}_{2}$, which has two imaginary frequencies and therefore is not an equilibrium structure. The $\mathrm{ClCl}: \mathrm{PH}_{3}$ binary complex has a binding energy of $14.3 \mathrm{~kJ} \cdot \mathrm{mol}^{-1}$ at a $\mathrm{P}-\mathrm{Cl}$ distance of $3.048 \AA$. The binding energies of the ternary complexes $\mathrm{ClCl}: \mathrm{PH}_{3}: \mathrm{N}$-base increase relative to the binary, vary from 18.3 to $20.0 \mathrm{~kJ} \cdot \mathrm{mol}^{-1}$, and decrease with respect to the nitrogen base in the order

$$
\mathrm{NCH}>\mathrm{NH}_{3}=\mathrm{NCF}>\mathrm{NCCN}
$$

The nonadditivities of the binding energies are negative, with values between -1.6 and $-3.4 \mathrm{~kJ} \cdot \mathrm{mol}^{-1}$. These values indicate that the ternary complexes are more stable than the two corresponding isolated binary complexes. However, it should be kept in mind that the binding energies of the nonequilibrium binary complexes $\mathrm{PH}_{3}$ :N-base of $\mathrm{C}_{3 v}$ symmetry have been used to compute nonadditivities.

All of the $\mathrm{P}-\mathrm{Cl}$ distances are shorter in the ternary $\mathrm{ClCl}: \mathrm{PH}_{3}: \mathrm{N}$-base complexes compared to the distance in the binary complex $\mathrm{ClCl}: \mathrm{PH}_{3}$. The longest distance of $2.993 \AA$ is found in the most weakly bound complex $\mathrm{ClCl}: \mathrm{PH}_{3}: \mathrm{NCCN}$. The $\mathrm{P}-\mathrm{Cl}$ distances in this complex and the binary complex $\mathrm{ClCl}: \mathrm{PH}_{3}$ are typical of distances for traditional $\mathrm{P} . . \mathrm{Cl}$ halogen bonds. However, the $\mathrm{P}-\mathrm{Cl}$ distances in the three remaining ternary complexes are much shorter, ranging from 2.276 to $2.318 \AA$. In addition, the $\mathrm{Cl}-\mathrm{Cl}$ distances in these same three complexes are significantly longer than the $\mathrm{Cl}-\mathrm{Cl}$ distances in the binary complex $\mathrm{ClCl}: \mathrm{PH}_{3}$ and the ternary complex $\mathrm{ClCl}: \mathrm{PH}_{3}: \mathrm{NCCN}$, as evident from Table 2. The lengthening of the $\mathrm{Cl}-\mathrm{Cl}$ bond and the shortening of the $\mathrm{P} \cdots \mathrm{Cl}$ bond in the complexes $\mathrm{ClCl}: \mathrm{PH}_{3}: \mathrm{NCH}, \mathrm{ClCl}: \mathrm{PH}_{3}: \mathrm{NH}_{3}$, and $\mathrm{ClCl}: \mathrm{PH}_{3}: \mathrm{NCF}$ suggest that the $\mathrm{P} \cdots \mathrm{Cl}$ bonds in these complexes are chlorine-shared halogen bonds. The $\mathrm{P}-\mathrm{N}$ distance in $\mathrm{ClCl}: \mathrm{PH}_{3}: \mathrm{NCCN}$ is $3.857 \AA$, but this distance decreases dramatically to about $3.4 \AA$ in the complexes with chlorine-shared halogen bonds, suggesting that the $\mathrm{P} \cdots \mathrm{N}$ pnicogen bond is also stronger in these three complexes. Figure 4 illustrates the structures of the complexes $\mathrm{ClCl}: \mathrm{PH}_{3}: \mathrm{NCH}$ and $\mathrm{ClCl}: \mathrm{PH}_{3}: \mathrm{NCCN}$.

The Wiberg bond indexes that are reported in Table 2 also differentiate between traditional and chlorine-shared halogen bonds. The index for the $\mathrm{P} \cdots \mathrm{Cl}$ bond is less than 0.1 for the $\mathrm{ClCl}: \mathrm{PH}_{3}: \mathrm{NCCN}$ complex but increases to about 0.5 in the 
Table 2. Binding Energies $(-\Delta E)$, Nonadditivities $\left(\delta \Delta E, \mathrm{~kJ}^{\circ} \mathrm{mol}^{-1}\right), \mathrm{P}-\mathrm{Cl}, \mathrm{P}-\mathrm{N}$, and $\mathrm{Cl}-\mathrm{Cl}$ Distances $(\mathrm{R}, \AA)$, and Wiberg Bond Indexes (WBI) in Ternary Complexes $\mathrm{ClCl}: \mathrm{PH}_{3}: \mathrm{N}$-base

$\begin{array}{lccccccccc}\text { N-base }= & -\Delta E & R(\mathrm{P}-\mathrm{Cl})^{a} & R(\mathrm{P}-\mathrm{N}) & R(\mathrm{Cl}-\mathrm{Cl})^{b} & \delta \Delta E & \mathrm{P}^{b} \mathrm{Cl} \mathrm{WBI}^{c} & \mathrm{P} \cdots \mathrm{N} \mathrm{WBI} & \mathrm{Cl}-\mathrm{Cl} \mathrm{WBI}{ }^{d} \\ \mathrm{NCH} & 20.0 & 2.300 & 3.405 & 2.288 & -3.4 & 0.528 & 0.006 & 0.453 \\ \mathrm{NH} & 18.7 & 2.276 & 3.439 & 2.279 & -3.2 & 0.504 & 0.004 & 0.473 \\ \mathrm{NCF} & 18.7 & 2.318 & 3.400 & 2.246 & -1.9 & 0.486 & 0.004 & 0.488 \\ \mathrm{NCCN} & 18.3 & 2.993 & 3.857 & 2.032 & -1.6 & 0.085 & 0.002 & 0.859\end{array}$

${ }^{a}$ The $\mathrm{P}-\mathrm{Cl}$ distance for the $\mathrm{P} \cdots \mathrm{Cl}$ halogen bond in $\mathrm{ClCl}: \mathrm{PH}_{3}$ is $3.048 \AA .{ }^{b} \mathrm{The} \mathrm{Cl}-\mathrm{Cl}$ distance in $\mathrm{ClCl}: \mathrm{PH}_{3}$ is $2.024 \AA .{ }^{c} \mathrm{The}$ Wiberg bond index for the $\mathrm{P} \cdots \mathrm{Cl}$ bond in $\mathrm{ClCl}: \mathrm{PH}_{3}$ is 0.069 . ${ }^{d}$ The Wiberg bond index for the $\mathrm{Cl}-\mathrm{Cl}$ bond in $\mathrm{ClCl}: \mathrm{PH}_{3}$ is 0.874 .

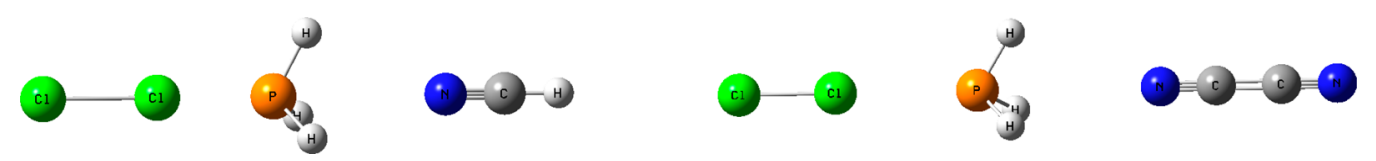

Figure 4. Complexes ClCl: $\mathrm{PH}_{3}: \mathrm{NCH}$ (left) and $\mathrm{ClCl}: \mathrm{PH}_{3}: \mathrm{NCCN}$ (right).

Table 3. Binding Energies $(-\Delta E)$, Nonadditivities $\left(\delta \Delta E, \mathrm{~kJ} \cdot \mathrm{mol}^{-1}\right), \mathrm{P}-\mathrm{Cl}, \mathrm{P}-\mathrm{N}$, and $\mathrm{F}-\mathrm{Cl}$ Distances $(\mathrm{R}, \AA)$, and Wiberg Bond Indexes (WBI) for Ternary Complexes $\mathrm{FCl}: \mathrm{PH}_{3}: \mathrm{N}$-base

$\begin{array}{lcccccccc}\mathrm{N}-\text { base }= & -\Delta E & R(\mathrm{P}-\mathrm{Cl})^{a, b} & R(\mathrm{P}-\mathrm{N}) & R(\mathrm{~F}-\mathrm{Cl})^{c} & \delta \Delta E & \mathrm{P} \cdots \mathrm{Cl} \mathrm{WBI}^{d} & \mathrm{P}^{c} \cdots \mathrm{N} \mathrm{WBI}^{e} & \mathrm{~F}^{2} \mathrm{Cl} \mathrm{WBI} \\ \mathrm{NCH} & 71.1 & 2.127 & 3.271 & 1.899 & -17.6 & 0.780 & 0.006 & 0.333 \\ \mathrm{NH}_{3} & 70.6 & 2.117 & 3.304 & 1.907 & -18.1 & 0.791 & 0.010 \\ \mathrm{NCF} & 69.4 & 2.132 & 3.283 & 1.893 & -16.7 & 0.773 & 0.005 & 0.323 \\ \mathrm{NCCN} & 63.4 & 2.148 & 3.377 & 1.879 & -10.4 & 0.752 & 0.004 & 0.339 \\ \mathrm{~N}_{2} & 56.3 & 2.168 & 3.611 & 1.862 & -3.5 & 0.724 & 0.002 & 0.378\end{array}$

${ }^{a}$ The $\mathrm{P}-\mathrm{Cl}$ distance in $\mathrm{FCl}: \mathrm{PH}_{3}$ is $2.182 \AA^{b}{ }^{b} \mathrm{The} \mathrm{P}-\mathrm{Cl}$ distance in ${ }^{+}\left(\mathrm{Cl}-\mathrm{PH}_{3}\right)$ is $1.955 \AA^{c} \mathrm{The} \mathrm{F}-\mathrm{Cl}$ distance in $\mathrm{FCl}: \mathrm{PH} \mathrm{H}_{3}$ is $1.851 \AA .{ }^{d}$ The WBI for the $\mathrm{P} \cdots \mathrm{Cl}$ bond in $\mathrm{FCl}: \mathrm{PH}_{3}$ is 0.705 . The value for the $\mathrm{P}-\mathrm{Cl}$ bond in the ion ${ }^{+}\left(\mathrm{Cl}-\mathrm{PH}_{3}\right)$ is $1.027 .{ }^{e}$ The WBI for the $\mathrm{P} \cdots \mathrm{N}$ bonds in the nonequilibrium complexes $\mathrm{PH}_{3}: \mathrm{N}$-base are 0.001 , except for the base NCCN, in which case the value is $0.002 .{ }^{f_{\mathrm{T}}}$ The WBI for the $\mathrm{F}-\mathrm{Cl}$ bond in $\mathrm{FCl}: \mathrm{PH}_{3}$ is 0.392 .

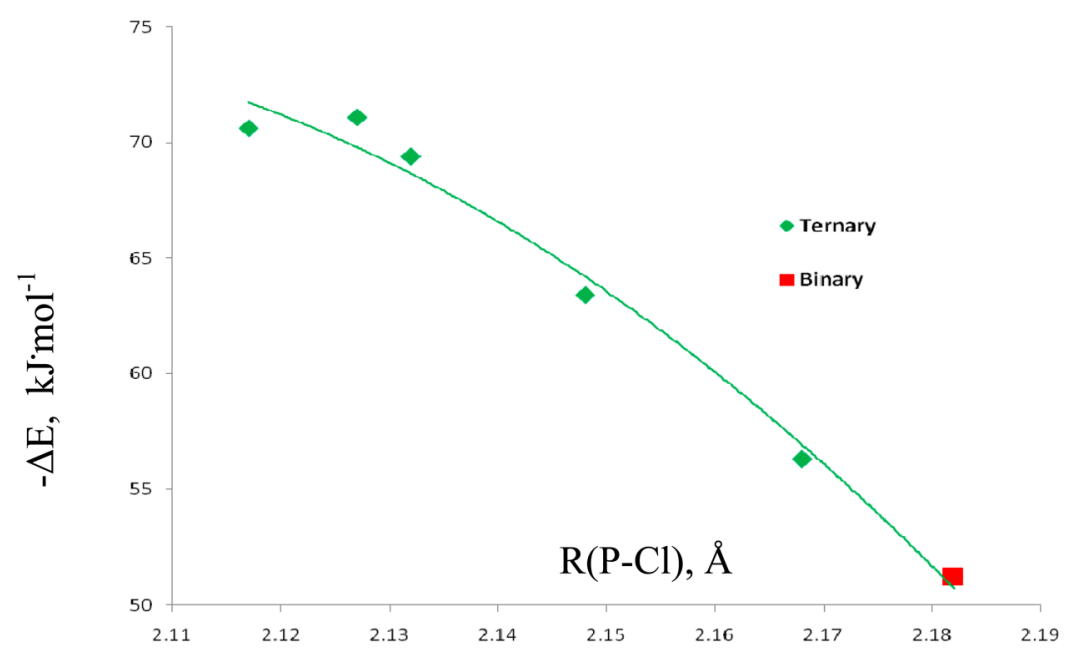

Figure 5. Binding energies of the ternary complexes $\mathrm{FCl}: \mathrm{PH}_{3}: \mathrm{N}$-base and the binary complex $\mathrm{FCl}: \mathrm{PH}_{3}$ versus the $\mathrm{P}-\mathrm{Cl}$ distance.

three complexes with chlorine-shared halogen bonds. The Wiberg bond index for the $\mathrm{Cl}-\mathrm{Cl}$ bond in the $\mathrm{ClCl}: \mathrm{PH}_{3}: \mathrm{NCCN}$ complex is 0.9 , but it decreases to about 0.5 in the three remaining ternary complexes. The Wiberg bond indexes for the $\mathrm{P} \cdots \mathrm{N}$ pnicogen bonds vary from 0.002 to 0.006 , suggesting that these bonds are weak intermolecular bonds.

$\mathrm{FCl}: \mathrm{PH}_{3}: \mathrm{N}$-base Ternary Complexes. Table S4 of the Supporting Information provides the structures, total energies, and molecular graphs of the $\mathrm{FCl}: \mathrm{PH}_{3}: \mathrm{N}$-base complexes with $C_{3 v}$ symmetry, all of which are equilibrium structures with no imaginary frequencies. Table 3 presents the binding energies, $\mathrm{P}-\mathrm{Cl}, \mathrm{P}-\mathrm{N}$, and $\mathrm{F}-\mathrm{Cl}$ distances, and nonadditivities of binding energies for these same complexes. These complexes are significantly more stable than the $\mathrm{ClCl}: \mathrm{PH}_{3}: \mathrm{N}$-base complexes, a reflection of the relative stabilities of the binary complexes $\mathrm{FCl}: \mathrm{PH}_{3}$ and $\mathrm{ClCl}: \mathrm{PH}_{3}$. The stronger of the two interactions in the complexes $\mathrm{FCl}: \mathrm{PH}_{3}: \mathrm{N}$-base is undoubtedly the $\mathrm{P} \cdots \mathrm{Cl}$ halogen bond, but that bond further stabilizes the $\mathrm{P} \cdots \mathrm{N}$ pnicogen bond formed through the lone-pair hole on P. The binding energies of these complexes range from 56 to $71 \mathrm{~kJ}$. $\mathrm{mol}^{-1}$, compared to a binding energy of $51 \mathrm{~kJ} \cdot \mathrm{mol}^{-1}$ for $\mathrm{FCl}: \mathrm{PH}_{3}$. In the ternary complexes, the binding energies decrease with respect to the nitrogen base in the order

$$
\mathrm{NCH} \approx \mathrm{NH}_{3}>\mathrm{NCF}>\mathrm{NCCN}>\mathrm{N}_{2}
$$


That the $\mathrm{P} \cdots \mathrm{Cl}$ halogen bond is the prime determiner of the total binding energies of these complexes can be seen from Figure 5, which is a plot of the binding energies of the ternary complexes $\mathrm{FCl}: \mathrm{PH}_{3}: \mathrm{N}$-base and the binary complex $\mathrm{FCl}: \mathrm{PH}_{3}$ versus the $\mathrm{P}-\mathrm{Cl}$ distance. The correlation coefficient of the second-order trendline is 0.986 . The correlation would not be this good if the $\mathrm{P} \cdots \mathrm{N}$ pnicogen bond were stronger.

The nonadditivities of binding energies are always negative, indicating that energetic effects are synergistic in these complexes. Moreover, the nonadditivity is greatest in the $\mathrm{FCl}: \mathrm{PH}_{3}: \mathrm{NH}_{3}$ complex. Nonadditivities decrease in absolute value with respect to the nitrogen base in the order

$$
\mathrm{NH}_{3}>\mathrm{NCH}>\mathrm{NCF} \gg \mathrm{NCCN} \gg \mathrm{N}_{2}
$$

Intermolecular distances also reflect the stronger intermolecular bonds in the ternary complexes. The $\mathrm{P}-\mathrm{Cl}$ distances in these complexes range from 2.117 to $2.168 \AA$, compared to $2.182 \AA$ for $\mathrm{FCl}: \mathrm{PH}_{3}$. These short distances suggest that the P... $\mathrm{Cl}$ bonds in the ternary complexes have acquired increased chlorine-shared character. ${ }^{51}$ The $\mathrm{P}-\mathrm{Cl}$ bond lengths decrease as the binding energies increase, except for a reversal of $\mathrm{NCH}$ and $\mathrm{NH}_{3}$. This reversal suggests that the halogen bond may be stronger in $\mathrm{FCl}: \mathrm{PH}_{3}: \mathrm{NH}_{3}$, consistent with the stronger electron-donating ability of $\mathrm{NH}_{3}$ compared to that of $\mathrm{NCH}$. However, the $\mathrm{P}-\mathrm{N}$ distance in $\mathrm{FCl}: \mathrm{PH}_{3}: \mathrm{NH}_{3}$ is longer than the $\mathrm{P}-\mathrm{N}$ distances in both $\mathrm{FCl}: \mathrm{PH}_{3}: \mathrm{NCH}$ and $\mathrm{FCl}: \mathrm{PH}_{3}: \mathrm{NCF}$. This may be due in part to the need to reduce the electrostatic and/ or steric repulsions between $\mathrm{NH}_{3}$ and $\mathrm{PH}_{3}$. The $\mathrm{F}-\mathrm{Cl}$ distances also increase in the ternary complexes stabilized by chlorineshared halogen bonds relative to the binary complex. They range between 1.862 and $1.907 \AA$, compared to $1.851 \AA$ in the binary complex, an indication that the $\mathrm{P}$... $\mathrm{Cl}$ bonds have increased chlorine-shared character in the ternary complexes. The $\mathrm{P}-\mathrm{N}$ distances in the $\mathrm{FCl}: \mathrm{PH}_{3}: \mathrm{N}$-base complexes vary between 3.271 and $3.611 \AA$. For a fixed base, the $\mathrm{P}-\mathrm{N}$ distance in a $\mathrm{FCl}: \mathrm{PH}_{3}: \mathrm{N}$-base complex is shorter than that in the corresponding $\mathrm{ClCl}: \mathrm{PH}_{3}: \mathrm{N}$-base complex, indicating that the $\mathrm{P} \cdots \mathrm{N}$ pnicogen bond is also stronger in the complexes with $\mathrm{FCl}$.

The Wiberg bond indexes are also reported in Table 3. The indexes for the $\mathrm{P} \cdots \mathrm{Cl}$ halogen bonds are between 0.724 and 0.791 for the ternary complexes, compared to 0.705 for the corresponding binary complex. Moreover, the largest index of 0.791 is found for the $\mathrm{P} \cdots \mathrm{Cl}$ bond in $\mathrm{FCl}: \mathrm{PH}_{3}: \mathrm{NH}_{3}$, indicating that the strongest halogen bond is found in this complex. The Wiberg bond index for the $\mathrm{F}-\mathrm{Cl}$ bond decreases as expected in ternary complexes relative to the binary complex. These changes are consistent with an increased chlorine-shared character of the $\mathrm{P} \cdots \mathrm{Cl}$ bonds in the ternary complexes. Wiberg bond indexes for the $\mathrm{P} \cdots \mathrm{N}$ pnicogen bonds are much smaller and range from 0.002 in $\mathrm{FCl}: \mathrm{PH}_{3}: \mathrm{N}_{2}$ to 0.010 in $\mathrm{FCl}: \mathrm{PH}_{3}: \mathrm{NH}_{3}$. Although these are still weak pnicogen bonds, they are stronger than the $\mathrm{P} \cdots \mathrm{N}$ bond in the corresponding ternary complexes $\mathrm{ClCl}: \mathrm{PH}_{3}: \mathrm{N}-$ base.

Although it was not possible to compute the charge-transfer energies across intermolecular bonds in these complexes with chlorine-shared halogen bonds, their geometries are indicative of the direction of electron transfer across both pnicogen and halogen bonds. The direction of charge-transfer across the P... $\mathrm{N}$ pnicogen bond is from the $\mathrm{N}$ lone pair to $\mathrm{P}$ through its lonepair hole. For the $\mathrm{P} \cdots \mathrm{Cl}$ halogen bond, the geometries of these complexes are conducive for charge donation from the lone pair on $\mathrm{P}$ to the $\sigma$ antibonding $\mathrm{Cl}-\mathrm{F}$ orbital. Specifically, the $\mathrm{Cl}-\mathrm{P}-$
$\mathrm{H}$ angles in the $\mathrm{FCl}: \mathrm{PH}_{3}: \mathrm{N}$-base complexes are $116^{\circ}$, thereby directing the lone pair on $\mathrm{P}$ toward $\mathrm{Cl}$. The linear $\mathrm{F}-\mathrm{Cl}-\mathrm{P}$ arrangement aligns the $\sigma$-hole on $\mathrm{Cl}$ with the $\mathrm{P}$ lone pair. Figure 6 illustrates charge transfer in the complex $\mathrm{FCl}: \mathrm{PH}_{3}: \mathrm{NH}_{3}$. Charge transfer in the same direction across adjacent intermolecular bonds leads to synergistic energetic effects. ${ }^{52-54}$

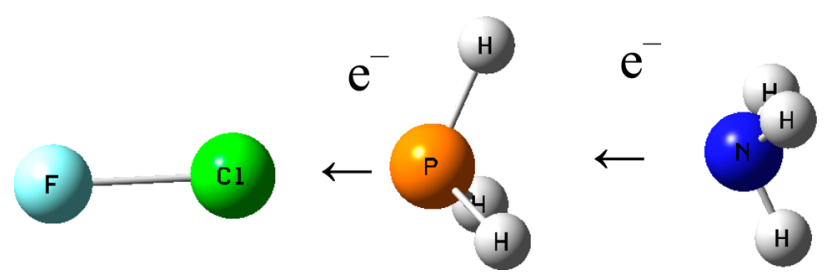

Figure 6. Structure of the ternary complex $\mathrm{FCl}: \mathrm{PH}_{3}: \mathrm{NH}_{3}$ indicating the direction of charge transfer across the halogen and pnicogen bonds.

The changing nature of the $\mathrm{P}-\mathrm{Cl}$ bond in the binary and ternary complexes with $\mathrm{ClCl}$ and $\mathrm{ClF}$ is also reflected in the values of the Laplacians and the energy densities at the BCPs. The complexes $\mathrm{ClCl}: \mathrm{PH}_{3}$ and $\mathrm{ClCl}: \mathrm{PH}_{3}: \mathrm{NCCN}$ with the longest $\mathrm{P}-\mathrm{Cl}$ distances have positive values of the Laplacian and total energy density, $H$, values around $0.0 \mathrm{au}$. These values correspond to traditional intermolecular bonds. The remaining ternary complexes with $\mathrm{ClCl}$ have positive values of the Laplacian but negative values of $H$ between -0.03 and -0.04 $\mathrm{au}$, indicating that they have acquired some covalent character. All of the complexes with $\mathrm{FCl}$ have negative values of the Laplacian and total energy density values between -0.05 and $-0.07 \mathrm{au}$. These chlorine-shared halogen bonds have increased covalent character as the $\mathrm{P}-\mathrm{Cl}$ distance further contracts. Figure 7 illustrates these changes in the Laplacian as a function of the $\mathrm{P}-\mathrm{Cl}$ distance.

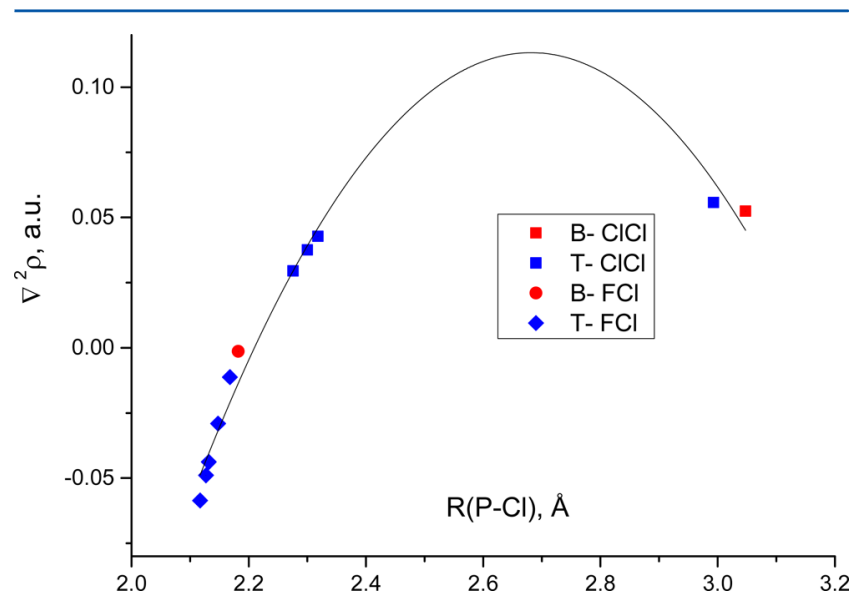

Figure 7. Laplacians at the $\mathrm{P} \cdots \mathrm{Cl} \mathrm{BCPs}$ versus the $\mathrm{P}-\mathrm{Cl}$ distance in binary complexes $\mathrm{ClCl}: \mathrm{NH}_{3}(\mathrm{~B}-\mathrm{ClCl})$ and $\mathrm{FCl}: \mathrm{NH}_{3}(\mathrm{~B}-\mathrm{FCl})$ and ternary complexes $\mathrm{ClCl}: \mathrm{NH}_{3}: \mathrm{N}$-base $(\mathrm{T}-\mathrm{ClCl})$ and $\mathrm{FCl}: \mathrm{PH}_{3}: \mathrm{N}$-base (T-FCl).

Spin-Spin Coupling Constants for Complexes $\mathrm{ClCl}: \mathrm{PH}_{3}: \mathrm{N}$ base and $\mathrm{FCl}: \mathrm{PH}_{3}: \mathrm{N}$-base. The components of the spin-spin coupling constants ${ }^{1 \mathrm{x}} \mathrm{J}(\mathrm{P}-\mathrm{Cl})$ for coupling across $\mathrm{P}$... Cl halogen bonds and ${ }^{1 \mathrm{p}} \mathrm{J}(\mathrm{P}-\mathrm{N})$ for coupling across $\mathrm{P} \cdots \mathrm{N}$ pnicogen bonds are reported in Table S5 for the complexes $\mathrm{ClCl}: \mathrm{PH}_{3}$ and $\mathrm{ClCl}: \mathrm{PH}_{3}: \mathrm{N}$-base and in Table S6 for the complexes FCl: $\mathrm{PH}_{3}$ 
and $\mathrm{FCl}: \mathrm{PH}_{3}: \mathrm{N}$-base, as well as ${ }^{1} J(\mathrm{P}-\mathrm{Cl})$ for the ion $+\left(\mathrm{Cl}-\mathrm{PH}_{3}\right)$. The $\mathrm{FC}$ term is the dominant term contributing to ${ }^{1 \mathrm{x}} \mathrm{J}(\mathrm{P}-\mathrm{Cl})$ and ${ }^{1 \mathrm{p}} J(\mathrm{P}-\mathrm{N})$ for coupling across both halogen bonds and pnicogen bonds. It is this term that determines the variation of these two coupling constants in the complexes. The FC term is also a good approximation to ${ }^{1} J(\mathrm{P}-\mathrm{Cl})$ for the ion ${ }^{+}\left(\mathrm{Cl}-\mathrm{PH}_{3}\right)$, but this is true only because the PSO and SD terms are of opposite sign and tend to cancel. Only total $J$ values are presented and discussed below.

${ }^{1 \mathrm{x}} \mathrm{J}(\mathrm{P}-\mathrm{Cl})$ values are reported in Table 4 and vary from 217 to $305 \mathrm{~Hz}$ for $\mathrm{ClCl}: \mathrm{PH}_{3}: \mathrm{N}$-base complexes and from 53 to 179

Table 4. ${ }^{1 \mathrm{x}} \mathrm{J}(\mathrm{P}-\mathrm{Cl})$ and ${ }^{1 \mathrm{p}} \mathrm{J}(\mathrm{P}-\mathrm{N})(\mathrm{Hz})$ in Ternary Complexes $\mathrm{ClCl}: \mathrm{PH}_{3}: \mathrm{N}$-base and $\mathrm{FCl}: \mathrm{PH}_{3}: \mathrm{N}$-base

\begin{tabular}{|c|c|c|c|c|}
\hline \multirow[b]{2}{*}{$\mathrm{N}$-base $=$} & \multicolumn{2}{|c|}{$\mathrm{ClCl}: \mathrm{PH}_{3}: \mathrm{N}$-base } & \multicolumn{2}{|c|}{$\mathrm{FCl}: \mathrm{PH}_{3}: \mathrm{N}$-base } \\
\hline & ${ }^{1 \mathrm{x}} J(\mathrm{P}-\mathrm{Cl})^{a}$ & ${ }^{\mathrm{lp}} J(\mathrm{P}-\mathrm{N})$ & ${ }^{1 \mathrm{x}} J(\mathrm{P}-\mathrm{Cl})^{b, c}$ & ${ }^{1 \mathrm{p}} J(\mathrm{P}-\mathrm{N})$ \\
\hline $\mathrm{NCH}$ & 268.9 & 8.3 & 73.5 & 3.6 \\
\hline $\mathrm{NH}_{3}$ & 217.1 & 8.7 & 53.3 & 2.9 \\
\hline NCF & 305.4 & 9.5 & 86.6 & 4.8 \\
\hline $\mathrm{NCCN}$ & 256.1 & 1.7 & 126.8 & 4.7 \\
\hline $\mathrm{N}_{2}$ & & & 178.8 & 3.2 \\
\hline
\end{tabular}

${ }^{a}{ }^{1 \mathrm{x}} \mathrm{J}(\mathrm{P}-\mathrm{Cl})$ for $\mathrm{ClCl}: \mathrm{PH}_{3}$ is $224.3 \mathrm{~Hz} \cdot{ }^{b{ }_{1 \mathrm{x}}} \mathrm{J}(\mathrm{P}-\mathrm{Cl})$ for $\mathrm{FCl}: \mathrm{PH}_{3}$ is 213.4 $\mathrm{Hz} .{ }^{c 1} J(\mathrm{P}-\mathrm{Cl})$ for the cation ${ }^{+}\left(\mathrm{Cl}-\mathrm{PH}_{3}\right)$ is $-119.9 \mathrm{~Hz}$.

$\mathrm{Hz}$ for the complexes $\mathrm{FCl}: \mathrm{PH}_{3}: \mathrm{N}$-base. Why do $\mathrm{ClCl}: \mathrm{PH}_{3}: \mathrm{NCH}$ and $\mathrm{ClCl}: \mathrm{PH}_{3}: \mathrm{NCCN}$ have similar coupling constants at two very different distances, and why does $\mathrm{ClCl}: \mathrm{PH}_{3}: \mathrm{NCF}$ have the largest coupling constant at a distance intermediate between the $\mathrm{P}-\mathrm{Cl}$ distances in $\mathrm{ClCl}: \mathrm{PH}_{3}: \mathrm{NCH}$ and $\mathrm{ClCl}: \mathrm{PH}_{3}: \mathrm{NCCN}$ ? Why are the coupling constants for $\mathrm{FCl}: \mathrm{PH}_{3}: \mathrm{N}$-base so much smaller than those for $\mathrm{ClCl}: \mathrm{PH}_{3}: \mathrm{N}$ base despite the shorter distances in the latter complexes? Insight into the answers to these questions comes from recognition of the changing nature of the halogen bond in these complexes. Figure 8 illustrates the variation ${ }^{1 x} \mathrm{~J}(\mathrm{P}-\mathrm{Cl})$ as a function of the $\mathrm{P}-\mathrm{Cl}$ distance for the binary and ternary complexes. It has been noted previously that ${ }^{1 x} J(\mathrm{P}-\mathrm{Cl})$ increases as the $\mathrm{P}-\mathrm{Cl}$ distance decreases for complexes with traditional halogen bonds, and this trend is reflected in the values for the binary complex $\mathrm{ClCl}: \mathrm{PH}_{3}$ and the ternary complex $\mathrm{ClCl}: \mathrm{PH}_{3}: \mathrm{NCCN}$. However, if there is a change in halogen-bond type along the distance coordinate, there will be a change in the curvature of the trendline as the values of ${ }^{1 \mathrm{x}} J(\mathrm{P}-\mathrm{Cl})$ begin to decrease with decreasing distance. This is evident in Figure 8 from the points representing the complexes $\mathrm{ClCl}: \mathrm{PH}_{3}: \mathrm{NCH}, \mathrm{ClCl}: \mathrm{PH}_{3}: \mathrm{NH}_{3}$, and ClCl: $\mathrm{PH}_{3}: \mathrm{NCF}$. At even shorter distances, values of ${ }^{1 \mathrm{x}} \mathrm{J}(\mathrm{P}-\mathrm{Cl})$ continue to decrease with decreasing distance and approach the value of ${ }^{1} \mathrm{~J}(\mathrm{P}-\mathrm{Cl})$ for the cation. Decreasing ${ }^{1 \mathrm{x}} \mathrm{J}(\mathrm{P}-\mathrm{Cl})$ with decreasing $\mathrm{P}-\mathrm{Cl}$ distance is behavior typical of chlorine-shared halogen bonds. ${ }^{51}$ Figure 8 also illustrates the greater degree of chlorine-shared character in the ternary complexes with $\mathrm{FCl}$ compared to that with $\mathrm{ClCl}$. The quadratic trendline in Figure 8 has a correlation coefficient of 0.955 .

In contrast, the values of ${ }^{1 \mathrm{p}} J(\mathrm{P}-\mathrm{N})$ across the $\mathrm{P} \cdots \mathrm{N}$ pnicogen bond, which are reported in Table 4, are relatively small. In the nonequilibrium binary complexes, values of this coupling constant are $1.5 \mathrm{~Hz}$ or less. ${ }^{1 \mathrm{p}} J(\mathrm{P}-\mathrm{N})$ is $2 \mathrm{~Hz}$ for the $\mathrm{ClCl}: \mathrm{PH}_{3}: \mathrm{NCCN}$ complex at a long $\mathrm{P}-\mathrm{N}$ distance but increases to between 8 and $10 \mathrm{~Hz}$ for the remaining three complexes at shorter $\mathrm{P}-\mathrm{N}$ distances. ${ }^{1 \mathrm{p}} \mathrm{J}(\mathrm{P}-\mathrm{N})$ values range from $2.9 \mathrm{~Hz}$ in $\mathrm{FCl}: \mathrm{PH}_{3}: \mathrm{NH}_{3}$ to $4.8 \mathrm{~Hz}$ in $\mathrm{FCl}: \mathrm{PH}_{3}: \mathrm{NCF}$. Thus, the values in the ternary complexes with $\mathrm{NCH}, \mathrm{NH}_{3}$, and $\mathrm{NCF}$ are smaller than those in the corresponding $\mathrm{ClCl}: \mathrm{PH}_{3}: \mathrm{N}$ base complexes, despite the longer distances in the latter. This suggests that $\mathrm{FCl}$ reduces the electron density at $\mathrm{P}$ in the ground state and the excited states that couple to it through the FC operator.

$\mathrm{FBr}: \mathrm{PH}_{3}: \mathrm{N}$-base Ternary Complexes. The structures, total energies, and molecular graphs of the ternary complexes $\mathrm{FBr}: \mathrm{PH}_{3}: \mathrm{N}$-base are reported in Table $\mathrm{S} 7$ of the Supporting Information. Table 5 provides the binding energies and $\mathrm{P}-\mathrm{Br}$, $\mathrm{P}-\mathrm{N}$, and $\mathrm{F}-\mathrm{Br}$ distances, and Figure 9 illustrates the $\mathrm{FBr}: \mathrm{PH}_{3}: \mathrm{NCH}$ complex. The binding energies of $\mathrm{FBr}: \mathrm{PH}_{3}: \mathrm{N}-$

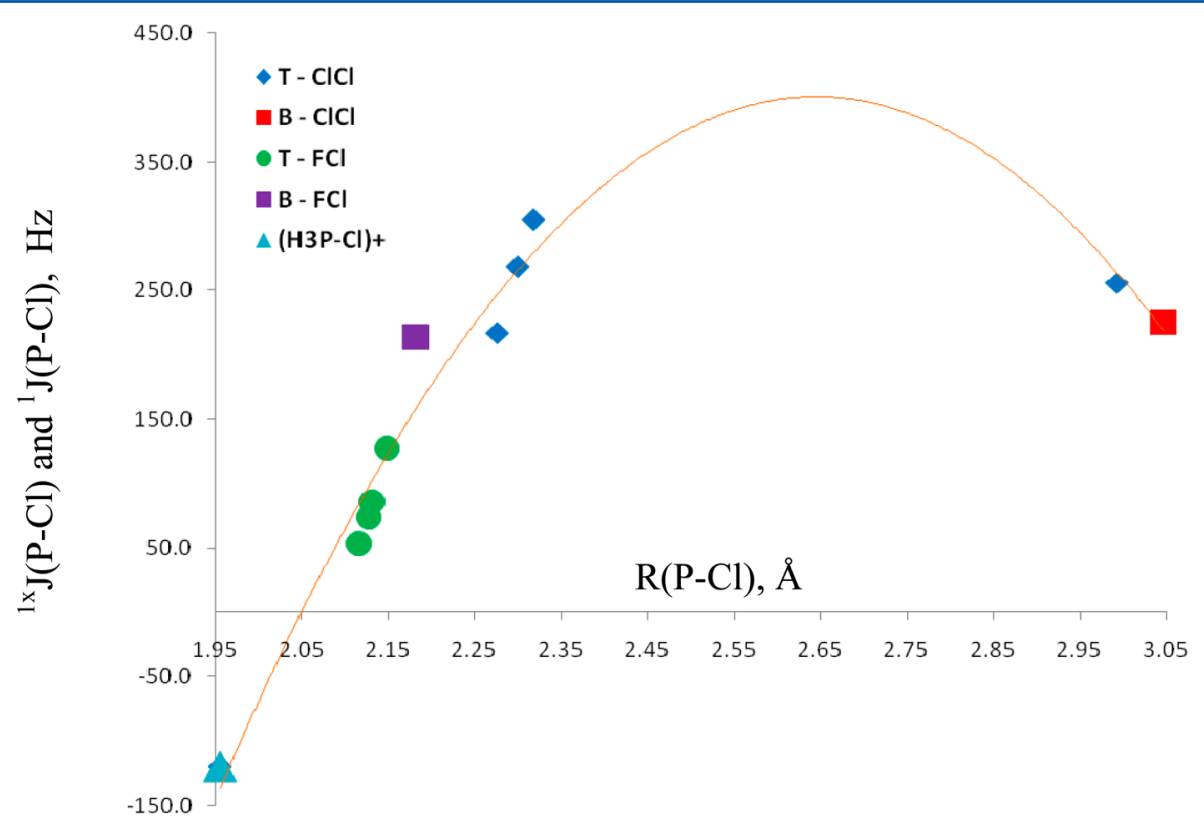

Figure 8. Spin-spin coupling constants ${ }^{1 \mathrm{x}} \mathrm{J}(\mathrm{P}-\mathrm{Cl})$ for complexes $\mathrm{ClCl}: \mathrm{PH}_{3}$ (B-ClCl), ClCl: $\mathrm{PH}_{3}: \mathrm{N}-$ base $(\mathrm{T}-\mathrm{ClCl}), \mathrm{FCl}: \mathrm{PH} \mathrm{H}_{3}(\mathrm{~B}-\mathrm{FCl})$, and FCl: $\mathrm{PH}_{3}: \mathrm{N}$-base $(\mathrm{T}-\mathrm{FCl})$ and ${ }^{1} J(\mathrm{P}-\mathrm{Cl})$ for ${ }^{+}\left(\mathrm{Cl}-\mathrm{PH}_{3}\right)$ versus the $\mathrm{P}-\mathrm{Cl}$ distance. 
Table 5. Binding Energies $(-\Delta E)$, Nonadditivities $\left(\delta \Delta E, \mathrm{~kJ}^{\circ} \mathrm{mol}^{-1}\right), \mathrm{P}-\mathrm{Br}, \mathrm{P}-\mathrm{N}$, and $\mathrm{F}-\mathrm{Br}$ Distances $(\mathrm{R}, \AA)$, and Wiberg Bond Indexes (WBI) for Ternary Complexes $\mathrm{FBr}: \mathrm{PH}_{3}: \mathrm{N}$-base

\begin{tabular}{|c|c|c|c|c|c|c|c|c|}
\hline $\mathrm{N}$-base $=$ & $-\Delta E^{a}$ & $R(\mathrm{P}-\mathrm{Br})^{b}$ & $R(\mathrm{P}-\mathrm{N})$ & $R(\mathrm{~F}-\mathrm{Br})^{c}$ & $\delta \Delta E$ & $\mathrm{P} \cdots \mathrm{Br} \mathrm{WBI}^{d}$ & $\mathrm{P} \cdots \mathrm{N}$ WBI & $\mathrm{F}-\mathrm{Br} \mathrm{WBI}^{e}$ \\
\hline $\mathrm{NCH}$ & 82.5 & 2.344 & 3.358 & 1.927 & -15.2 & 0.690 & 0.004 & 0.386 \\
\hline $\mathrm{NH}_{3}$ & 81.1 & 2.340 & 3.422 & 1.929 & -14.9 & 0.695 & 0.006 & 0.381 \\
\hline $\mathrm{NCF}$ & 81.1 & 2.347 & 3.356 & 1.924 & -14.6 & 0.686 & 0.004 & 0.386 \\
\hline NCCN & 76.2 & 2.360 & 3.654 & 1.914 & -9.4 & 0.666 & 0.003 & 0.389 \\
\hline $\mathrm{N}_{2}$ & 69.9 & 2.377 & 3.654 & 1.903 & -3.4 & 0.641 & 0.002 & 0.403 \\
\hline
\end{tabular}

${ }^{a_{T}}$ The binding energy of $\mathrm{FBr}: \mathrm{PH}_{3}$ is $65.0 \mathrm{~kJ} \cdot \mathrm{mol}^{-1} .{ }^{b} \mathrm{The} \mathrm{P}-\mathrm{Br}$ distance in $\mathrm{FBr}: \mathrm{PH}_{3}$ is $2.391 \AA$, and that in ${ }^{+}\left(\mathrm{Br}-\mathrm{PH} \mathrm{H}_{3}\right)$ is $2.112 \AA .{ }^{c} \mathrm{The} \mathrm{F}-\mathrm{Br}$ distance in $\mathrm{FBr}: \mathrm{PH}_{3}$ is $1.895 \AA .{ }^{d}$ The $\mathrm{P}-\mathrm{Br}$ WBI in $\mathrm{FBr}: \mathrm{PH}_{3}$ is $0.622 .{ }^{e} \mathrm{The} \mathrm{F}-\mathrm{Br}$ WBI in $\mathrm{FBr}: \mathrm{PH}_{3}$ is 0.430 .

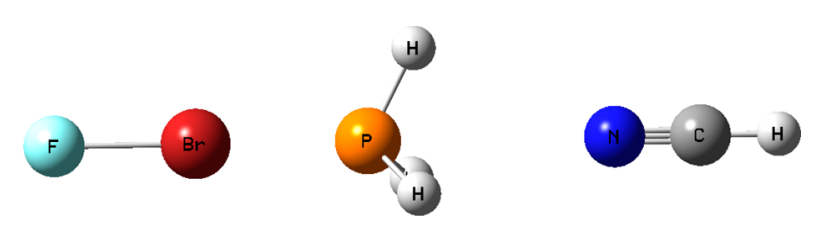

Figure 9. Structure of the complex $\mathrm{FBr}: \mathrm{PH}_{3}: \mathrm{NCH}$.

base complexes range from 70 to $83 \mathrm{~kJ} \cdot \mathrm{mol}^{-1}$ and decrease with respect to the nitrogen base in the order

$$
\mathrm{NCH}>\mathrm{NH}_{3}=\mathrm{NCF}>\mathrm{NCCN}>\mathrm{N}_{2}
$$

However, the binding energies of the three most strongly bound complexes differ by no more than $1.4 \mathrm{~kJ} \cdot \mathrm{mol}^{-1}$ over P$\mathrm{Br}$ distances that differ by no more than $0.007 \AA$. The binding energies of the ternary complexes $\mathrm{FBr}: \mathrm{PH}_{3}: \mathrm{N}$-base and the binary complex $\mathrm{FBr}: \mathrm{PH}_{3}$ show a second-order dependence on the $\mathrm{P}-\mathrm{Br}$ distance, with a correlation coefficient of 0.984 . As expected, for a given base, the binding energy of a $\mathrm{FBr}: \mathrm{PH}_{3}: \mathrm{N}$ base complex is greater than that of the corresponding $\mathrm{FCl}: \mathrm{PH}_{3}: \mathrm{N}$-base complex.

The nonadditivities of the binding energies of $\mathrm{FBr}: \mathrm{PH}_{3}: \mathrm{N}$ base complexes are also reported in Table 5. The nonadditivities are synergistic and vary from -3.4 to $-15.2 \mathrm{~kJ}$. $\mathrm{mol}^{-1}$. However, although the binding energy of a $\mathrm{FBr}: \mathrm{PH}_{3}: \mathrm{N}$ base complex is greater than the binding energy of the corresponding $\mathrm{FCl}: \mathrm{PH}_{3}: \mathrm{N}$-base complex, the nonadditivity of the binding energy of a $\mathrm{FBr}: \mathrm{PH}_{3}: \mathrm{N}$-base complex is smaller in absolute value than that of the corresponding complex with FCl. It appears that although the $\mathrm{P} \cdots \mathrm{Br}$ halogen bonds are stronger in the ternary $\mathrm{FBr}: \mathrm{PH}_{3}: \mathrm{N}$-base complexes relative to the $\mathrm{P} \cdots \mathrm{Cl}$ bonds in the ternary complexes $\mathrm{FCl}: \mathrm{PH}_{3}: \mathrm{N}$-base, the $\mathrm{P} \cdots \mathrm{N}$ pnicogen bonds are weaker.

Support for the existence of stronger halogen bonds but weaker pnicogen bonds in the $\mathrm{FBr}: \mathrm{PH}_{3}: \mathrm{N}$-base complexes relative to $\mathrm{FCl}: \mathrm{PH}_{3}: \mathrm{N}$-base comes from four observations. The first is the greater binding energy of the binary $\mathrm{FBr}: \mathrm{PH}_{3}$ complex compared to that of $\mathrm{FCl}: \mathrm{PH}_{3}$ and the observations made above based on nonadditivities and distance changes that both the $\mathrm{P} \cdots \mathrm{Br}$ and $\mathrm{P} \cdots \mathrm{Cl}$ bonds are strengthened in the ternary complexes. The second is the observation that for a fixed nitrogen base the $\mathrm{P}-\mathrm{N}$ bond distance in the $\mathrm{FBr}: \mathrm{PH}_{3}: \mathrm{N}$ base complex is longer than the $\mathrm{P}-\mathrm{N}$ distance in the corresponding $\mathrm{FCl}: \mathrm{PH}_{3}: \mathrm{N}$-base complex, indicating that the $\mathrm{P} \cdots \mathrm{N}$ bond is weaker in the ternary complex with $\mathrm{FBr}$. The third piece of supporting evidence comes from the Wiberg bond indexes for P...N bonds that are reported in Tables 3 and 5. For a fixed nitrogen base, the Wiberg bond index for the P... $\mathrm{N}$ bond is smaller in the $\mathrm{FBr}: \mathrm{PH}_{3}: \mathrm{N}$-base complex compared to that in the corresponding $\mathrm{FCl}: \mathrm{PH}_{3}: \mathrm{N}$-base complex, except for the complexes with $\mathrm{N}_{2}$, for which they are equal. Finally, the value of the lone-pair hole at $\mathrm{P}$ on the MEP isosurface of $\mathrm{FBr}: \mathrm{PH}_{3}$ is $+0.052 \mathrm{au}$, which is less positive than the value of +0.061 au on the $\mathrm{FCl}: \mathrm{PH}_{3}$ surface. Hence, the electrostatic component of the $\mathrm{P} \cdots \mathrm{N}$ interaction in the latter complex is greater.

Are the halogen bonds in the three most strongly bound $\mathrm{FBr}: \mathrm{PH}_{3}: \mathrm{N}$-base complexes that have the shortest $\mathrm{P}-\mathrm{Br}$ distances bromine-transferred halogen bonds? To answer this question, it is advantageous to first recall that the $\mathrm{P} \cdots \mathrm{Cl}$ bonds in the $\mathrm{FCl}: \mathrm{PH}_{3}: \mathrm{N}$-base complexes with the shortest $\mathrm{P}-\mathrm{Cl}$ distances were not classified as chlorine-transferred halogen bonds. This determination was based on several observations. The first was the fact that the $\mathrm{P}-\mathrm{Cl}$ distances in these complexes are at least $0.222 \AA$ greater than the $\mathrm{P}-\mathrm{Cl}$ distance in the ion ${ }^{+}\left(\mathrm{Cl}-\mathrm{PH}_{3}\right)$. Second, the Wiberg bond index for ${ }^{+}\left(\mathrm{Cl}-\mathrm{PH}_{3}\right)$ is 1.03 , compared to the largest value of 0.79 for a ternary complex. The behavior of ${ }^{1 x} \mathrm{~J}(\mathrm{P}-\mathrm{Cl})$ versus the $\mathrm{P}-\mathrm{Cl}$ distance was the final piece of evidence that led to the conclusion that the $\mathrm{P} \cdots \mathrm{Cl}$ halogen bonds in the $\mathrm{FCl}: \mathrm{PH}_{3}: \mathrm{N}$ base complexes remain chlorine-shared halogen bonds but with increased chlorine-shared character relative to the binary complex. In the $\mathrm{FBr}: \mathrm{PH}_{3}: \mathrm{N}$-base complexes, the larger size of $\mathrm{Br}$ leads to a longer $\mathrm{P}-\mathrm{Br}$ bond length of $2.112 \AA$ in ${ }^{+}\left(\mathrm{Br}-\mathrm{PH}_{3}\right)$. The shortest $\mathrm{P}-\mathrm{Br}$ distance in the ternary complexes is $0.228 \AA$ longer than the distance in the ion. In addition, the largest Wiberg bond index for a $\mathrm{P}-\mathrm{Br}$ bond in a ternary complex is 0.70 , compared to 1.06 for the cation ${ }^{+}(\mathrm{Br}-$ $\mathrm{PH}_{3}$ ). These comparisons suggest that the $\mathrm{P} \cdots \mathrm{Br}$ bonds are not bromine-transferred halogen bonds but remain bromine-shared halogen bonds with increased bromine-shared character relative to the binary complex. The electron density properties at the $\mathrm{P}$...Br BCPs have positive values of the Laplacian and negative values of the energy density. This combination suggests that the $\mathrm{P} \cdots \mathrm{Br}$ bonds are less covalent that the $\mathrm{P} \cdot \mathrm{C} \mathrm{Cl}$ bonds, which have negative values of both parameters.

\section{CONCLUSIONS}

$\mathrm{Ab}$ initio MP2/aug'-cc-pVTZ calculations have been performed on the binary complexes $\mathrm{XY}: \mathrm{PH}_{3}$ for $\mathrm{XY}=\mathrm{ClCl}, \mathrm{FCl}$, and $\mathrm{FBr}$; and $\mathrm{PH}_{3}: \mathrm{N}$-base for N-base $=\mathrm{NCH}, \mathrm{NH}_{3}, \mathrm{NCF}, \mathrm{NCCN}$, and $\mathrm{N}_{2}$; and the corresponding ternary complexes $\mathrm{XY}: \mathrm{PH}_{3}: \mathrm{N}$-base, to investigate $\mathrm{P} \cdots \mathrm{N}$ pnicogen bond formation through the lonepair hole at $\mathrm{P}$ in the binary complexes and $\mathrm{P} \cdots \mathrm{N}$ pnicogen bond formation assisted by P...Y halogen bond formation through the $\sigma$-hole at Y. The results of these calculations support the following statements.

1. The binary complexes $\mathrm{PH}_{3}: \mathrm{N}$-base, which form through the lone-pair hole, have very small binding energies but are not equilibrium structures on their potential surfaces. However, the presence of the P...Y halogen bond makes 
$\mathrm{PH}_{3}$ a better electron-pair acceptor through its lone-pair hole, with the result that the ternary complexes $\mathrm{XY}: \mathrm{PH}_{3}: \mathrm{N}$-base are bound equilibrium structures, except for $\mathrm{ClCl}: \mathrm{PH}_{3}: \mathrm{N}_{2}$.

2. For a given nitrogen base, the binding energies of $\mathrm{XY}: \mathrm{PH}_{3}: \mathrm{N}$-base complexes decrease with respect to $\mathrm{XY}$ in the order $\mathrm{FBr}>\mathrm{FCl}>\mathrm{ClCl}$, which is the order of decreasing binding energies of the binary complexes $\mathrm{XY}: \mathrm{PH}_{3}$. The binding energies of the ternary complexes also increase with decreasing $\mathrm{P}-\mathrm{Y}$ distance, indicating that by far it is the halogen bond that is primarily responsible for the stabilities of these complexes. Nonadditivity effects on binding energies in ternary complexes are synergistic.

3. The halogen bonds in $\mathrm{ClCl}: \mathrm{PH}_{3}$ and $\mathrm{ClCl}: \mathrm{PH}_{3}: \mathrm{NCCN}$ are traditional halogen bonds, but in the remaining binary and ternary complexes, they are chlorine- or bromine-shared halogen bonds. As the strength of the nitrogen base increases, these bonds acquire increased halogen-shared character. For a given base, the halogenshared character of the $\mathrm{P} \cdots \mathrm{X}$ bond is greater in the $\mathrm{FCl}: \mathrm{PH}_{3}: \mathrm{N}$-base complex compared to that in $\mathrm{FBr}: \mathrm{PH}_{3}: \mathrm{N}$-base, which is greater than that of the corresponding $\mathrm{ClCl}: \mathrm{PH}_{3}: \mathrm{N}$-base complex.

4. For a given base, the $\mathrm{P} \cdots \mathrm{N}$ pnicogen bond is stronger in the ternary $\mathrm{FCl}: \mathrm{PH}_{3}: \mathrm{N}$-base complex compared to that in $\mathrm{FBr}: \mathrm{PH}_{3}: \mathrm{N}$-base. The weakest $\mathrm{P} \cdots \mathrm{N}$ bond is found in the $\mathrm{ClCl}: \mathrm{PH}_{3}: \mathrm{N}$-base complex.

5. Wiberg bond indexes and the Laplacians and energy densities at BCPs are consistent with the descriptions of the nature of $\mathrm{P} \cdots \mathrm{Cl}$ and $\mathrm{P} \cdots \mathrm{N}$ bonds based on energetic and structural data.

6. EOM-CCSD spin-spin coupling constants for the binary and ternary complexes with $\mathrm{ClCl}$ and $\mathrm{FCl}$ also provide evidence for the changing nature of the halogen bonds in these complexes. At long $\mathrm{P}-\mathrm{Cl}$ distances, ${ }^{1 x} \mathrm{~J}(\mathrm{P}-\mathrm{Cl})$ increases with decreasing $\mathrm{P}-\mathrm{Cl}$ distance. As the $\mathrm{P}-\mathrm{Cl}$ distance continues to decrease, ${ }^{1 x} \mathrm{~J}(\mathrm{P}-\mathrm{Cl})$ decreases and approaches the value of ${ }^{1} J(\mathrm{P}-\mathrm{Cl})$ for the cation ${ }^{+}\left(\mathrm{Cl}-\mathrm{PH}_{3}\right)$. Decreasing ${ }^{1 \mathrm{x}} \mathrm{J}(\mathrm{P}-\mathrm{Cl})$ with decreasing $\mathrm{P}-$ $\mathrm{Cl}$ distance is behavior typical of chlorine-shared halogen bonds.

7. For a given base, the coupling constant ${ }^{1 \mathrm{p}} J(\mathrm{P}-\mathrm{N})$ is greater in the $\mathrm{ClCl}: \mathrm{PH}_{3}: \mathrm{N}$-base complex compared to that in $\mathrm{FCl}: \mathrm{PH}_{3}: \mathrm{N}$-base, with one exception. This relationship occurs despite the shorter $\mathrm{P}-\mathrm{N}$ distance in the $\mathrm{FCl}: \mathrm{PH}_{3}: \mathrm{N}$-base complex and suggests that $\mathrm{FCl}$ reduces the overall s-electron density at $\mathrm{P}$ in the ground state and the excited states that couple to it through the Fermi-contact operator.

\section{ASSOCIATED CONTENT}

\section{S Supporting Information}

The Supporting Information is available free of charge on the

ACS Publications website at DOI: 10.1021/acs.jpca.6b12553.

Geometries, total energies, and molecular graphs of complexes; components of spin-spin coupling constants for complexes; and full citations for refs 38 and 48 (PDF)

\section{AUTHOR INFORMATION}

\section{Corresponding Authors}

*E-mail: jedelbene@ysu.edu. Phone: +1 330-609-5593 (J.E.D.B.)

*E-mail: ibon@iqm.csic.es. Phone: +34 91-5622900 (I.A.).

ORCID

Janet E. Del Bene: 0000-0002-9037-2822

\section{Notes}

The authors declare no competing financial interest.

\section{ACKNOWLEDGMENTS}

This work was carried out with financial support from the Ministerio de Economía y Competitividad (Project No. CTQ2015-63997-C2-2-P) and Comunidad Autónoma de Madrid (S2013/MIT2841, Fotocarbon). Thanks are also given to the Ohio Supercomputer Center, Irish Centre for High-End Computing (ICHEC), and CTI (CSIC) for their continued computational support.

\section{REFERENCES}

(1) Clark, T.; Hennemann, M.; Murray, J.; Politzer, P. Halogen Bonding: The s-Hole. J. Mol. Model. 2007, 13, 291-296.

(2) Politzer, P.; Murray, J. S.; Clark, T. Halogen Bonding: An Electrostatically-Driven Highly Directional Noncovalent Interaction. Phys. Chem. Chem. Phys. 2010, 12, 7748-7757.

(3) Clark, T. s-Holes. WIREs Comput. Mol. Sci. 2013, 3, 13-20.

(4) Murray, J. S.; Lane, P.; Politzer, P. A Predicted New Type of Directional Noncovalent Interaction. Int. J. Quantum Chem. 2007, 107, 2286-2292.

(5) Politzer, P.; Murray, J. S.; Clark, T. Halogen Bonding and Other s-Hole Interactions: A Perspective. Phys. Chem. Chem. Phys. 2013, 15, $11178-11189$.

(6) Minyaev, R. M.; Minkin, V. I. Theoretical Study of O $\rightarrow$ X (S, Se, Te) Coordination in Organic Compounds. Can. J. Chem. 1998, 76, $776-788$.

(7) Sanz, P.; Yáñez, M.; Mó, O. Resonance-Assisted Intramolecular Chalcogen-Chalcogen Interactions? Chem. - Eur. J. 2003, 9, 45484555.

(8) Bleiholder, C.; Werz, D. B.; Köppel, H.; Gleiter, R. Theoretical Investigations on Chalcogen-Chalcogen Interactions: What Makes These Nonbonded Interactions Bonding? J. Am. Chem. Soc. 2006, 128, 2666-2674.

(9) Sánchez-Sanz, G.; Trujillo, C.; Alkorta, I.; Elguero, J. Intermolecular Weak Interactions in HTeXH Dimers $(X=O, S, S e$, $\mathrm{Te})$ : Hydrogen Bonds, Chalcogen-Chalcogen Contacts and Chiral Discrimination. ChemPhysChem 2012, 13, 496-503.

(10) Scheiner, S. A New Noncovalent Force: Comparison of P...N Interaction with Hydrogen and Halogen Bonds. J. Chem. Phys. 2011, 134, 094315.

(11) Zahn, S.; Frank, R.; Hey-Hawkins, E.; Kirchner, B. Pnicogen Bonds: A New Molecular Linker? Chem. - Eur. J. 2011, 17, 60346038.

(12) Del Bene, J. E.; Alkorta, I.; Elguero, J. The Pnicogen Bond in Review: Structures, Binding Energies, Bonding Properties, and SpinSpin Coupling Constants of Complexes Stabilized by Pnicogen Bonds. In Noncovalent Forces: Challenges and Advances in Computational Chemistry and Physics; Scheiner, S., Ed.; Springer, 2015; Vol. 19, pp 191-263.

(13) Alkorta, I.; Rozas, I.; Elguero, J. Molecular Complexes between Silicon Derivatives and Electron-Rich Groups. J. Phys. Chem. A 2001, 105, 743-749.

(14) Bauzá, A.; Mooibroek, T. J.; Frontera, A. Tetrel-Bonding Interaction: Rediscovered Supramolecular Force? Angew. Chem., Int. Ed. 2013, 52, 12317-12321. 
(15) Grabowski, S. J. Tetrel Bond- $\sigma$-Hole Bond as a Preliminary Stage of the $\mathrm{S}_{\mathrm{N}} 2$ Reaction. Phys. Chem. Chem. Phys. 2014, 16, 18241834.

(16) Murray, J.; Lane, P.; Clark, T.; Riley, K.; Politzer, P. $\sigma$-Holes, $\pi$ Holes and Electrostatically-Driven Interactions. J. Mol. Model. 2012, 18, 541-548.

(17) Bauzá, A.; Mooibroek, T. J.; Frontera, A. The Bright Future of Unconventional $\sigma / \pi$-Hole Interactions. ChemPhysChem 2015, 16, 2496-2517.

(18) Solimannejad, M.; Ramezani, V.; Trujillo, C.; Alkorta, I.; Sánchez-Sanz, G.; Elguero, J. Competition and Interplay between $\sigma$ Hole and $\pi$-Hole Interactions: A Computational Study of 1:1 and 1:2 Complexes of Nitryl Halides $\left(\mathrm{O}_{2} \mathrm{NX}\right)$ with Ammonia. J. Phys. Chem. A 2012, 116, 5199-5206.

(19) Solimannejad, M.; Nassirinia, N.; Amani, S. A Computational Study of 1:1 and 1:2 Complexes of Nitryl Halides $\left(\mathrm{O}_{2} \mathrm{NX}\right)$ with $\mathrm{HCN}$ and HNC. Struct. Chem. 2013, 24, 651-659.

(20) Sánchez-Sanz, G.; Trujillo, C.; Solimannejad, M.; Alkorta, I.; Elguero, J. Orthogonal Interactions between Nitryl Derivatives and Electron Donors: Pnictogen Bonds. Phys. Chem. Chem. Phys. 2013, 15, 14310-14318.

(21) Bauzá, A.; Ramis, R.; Frontera, A. A Combined Theoretical and Cambridge Structural Database Study of $\pi$-Hole Pnicogen Bonding Complexes between Electron Rich Molecules and Both Nitro Compounds and Inorganic Bromides $\left(\mathrm{YO}_{2} \mathrm{Br}, \mathrm{Y}=\mathrm{N}, \mathrm{P}\right.$, and as). $\mathrm{J}$. Phys. Chem. A 2014, 118, 2827-2834.

(22) Báuza, A.; Frontera, A.; Mooibroek, T. J. $\pi$-Hole Interactions Involving Nitro Compounds: Directionality of Nitrate Esters. Cryst. Growth Des. 2016, 16, 5520-5524.

(23) Trujillo, C.; Sanchez-Sanz, G.; Alkorta, I.; Elguero, J. Halogen, Chalcogen and Pnictogen Interactions in $\left(\mathrm{XNO}_{2}\right)_{2}$ Homodimers $(\mathrm{X}=$ F, Cl, Br, I). New J. Chem. 2015, 39, 6791-6802.

(24) Quiñonero, D.; Bauza, A.; Sanchez-Sanz, G.; Trujillo, C.; Alkorta, I.; Elguero, J. Weak Interactions within Nitryl Halide Heterodimers. New J. Chem. 2016, 40, 9060-9072.

(25) Alkorta, I.; Elguero, J.; Del Bene, J. E. Pnicogen Bonded Complexes of $\mathrm{PO}_{2} \mathrm{X}(\mathrm{X}=\mathrm{F}, \mathrm{Cl})$ with Nitrogen Bases. J. Phys. Chem. A 2013, 117, 10497-10503.

(26) Alkorta, I.; Blanco, F.; Elguero, J.; Dobado, J. A.; Ferrer, S. M.; Vidal, I. Carbon ‥Carbon Weak Interactions. J. Phys. Chem. A 2009, 113, 8387-8393.

(27) Blanco, F.; Alkorta, I.; Rozas, I.; Solimannejad, M.; Elguero, J. A Theoretical Study of the Interactions of $\mathrm{NF}_{3}$ with Neutral Ambidentate Electron Donor and Acceptor Molecules. Phys. Chem. Chem. Phys. 2011, 13, 674-683.

(28) Alkorta, I.; Elguero, J.; Del Bene, J. E. Exploring the $\mathrm{PX}_{3}: \mathrm{NCH}$ and $\mathrm{PX}_{3}: \mathrm{NH}_{3}$ Potential Surfaces, with $\mathrm{X}=\mathrm{F}, \mathrm{Cl}$, and Br. Chem. Phys. Lett. 2015, 641, 84-89.

(29) Bauzá, A.; Mooibroek, T. J.; Frontera, A. $\sigma$-Hole Opposite to a Lone Pair: Unconventional Pnicogen Bonding Interactions between $\mathrm{ZF}_{3}(\mathrm{Z}=\mathrm{N}, \mathrm{P}, \mathrm{As}$, and $\mathrm{Sb})$ Compounds and Several Donors. ChemPhysChem 2016, 17, 1608-1614.

(30) Alkorta, I.; Elguero, J.; Del Bene, J. E. Characterizing Traditional and Chlorine-Shared Halogen Bonds in Complexes of Phosphine Derivatives with $\mathrm{ClF}$ and $\mathrm{Cl}_{2}$. J. Phys. Chem. A 2014, 118, 4222-4231.

(31) Pople, J. A.; Binkley, J. S.; Seeger, R. Theoretical Models Incorporating Electron Correlation. Int. J. Quantum Chem. 1976, 10, $1-19$.

(32) Krishnan, R.; Pople, J. A. Approximate Fourth-Order Perturbation Theory of the Electron Correlation Energy. Int. J. Quantum Chem. 1978, 14, 91-100.

(33) Bartlett, R. J.; Silver, D. M. Many-Body Perturbation Theory Applied to Electron Pair Correlation Energies. I. Closed-Shell FirstRow Diatomic Hydrides. J. Chem. Phys. 1975, 62, 3258-3268.

(34) Bartlett, R. J.; Purvis, G. D. Many-Body Perturbation Theory, Coupled-Pair Many-Electron Theory, and the Importance of Quadruple Excitations for the Correlation Problem. Int. J. Quantum Chem. 1978, 14, 561-581.
(35) Del Bene, J. E. Proton Affinities of Ammonia, Water, and Hydrogen Fluoride and Their Anions: A Quest for the Basis-Set Limit Using the Dunning Augmented Correlation-Consistent Basis Sets. J. Phys. Chem. 1993, 97, 107-110.

(36) Dunning, T. H. Gaussian Basis Sets for Use in Correlated Molecular Calculations. I. The Atoms Boron through Neon and Hydrogen. J. Chem. Phys. 1989, 90, 1007-1023.

(37) Woon, D. E.; Dunning, T. H. Gaussian Basis Sets for Use in Correlated Molecular Calculations. V. Core-Valence Basis Sets for Boron Through Neon. J. Chem. Phys. 1995, 103, 4572-4585.

(38) Frisch, M. J.; Trucks, G. W.; Schlegel, H. B.; Scuseria, G. E.; Robb, M. A.; Cheeseman, J. R.; Scalmani, G.; Barone, V.; Mennucci, B.; Petersson, G. A.; et al. Gaussian09, revision D.01.; Gaussian, Inc.: Wallingford, CT, 2009.

(39) Bader, R. F. W. A Quantum Theory of Molecular Structure and Its Applications. Chem. Rev. 1991, 91, 893-928.

(40) Bader, R. F. W. Atoms in Molecules, A Quantum Theory; Oxford University Press: Oxford, U.K., 1990.

(41) Popelier, P. L. A. Atoms In Molecules. An Introduction; Prentice Hall: Harlow, England, 2000.

(42) Matta, C. F.; Boyd, R. J. The Quantum Theory of Atoms in Molecules: From Solid State to DNA and Drug Design; Wiley-VCH: Weinheim, Germany, 2007.

(43) Keith, T. A. AIMAll, version 16.10.31; TK Gristmill Software: Overland Park, KS, 2011; aim.tkgristmill.com.

(44) Wiberg, K. B. Application of the Pople-Santry-Segal CNDO Method to the Cyclopropylcarbinyl and Cyclobutyl Cation and to Bicyclobutane. Tetrahedron 1968, 24, 1083-1096.

(45) Perera, S. A.; Nooijen, M.; Bartlett, R. J. Electron Correlation Effects on the Theoretical Calculation of Nuclear Magnetic Resonance Spin-Spin Coupling Constants. J. Chem. Phys. 1996, 104, 3290-3305.

(46) Perera, S. A.; Sekino, H.; Bartlett, R. J. Coupled-Cluster Calculations of Indirect Nuclear Coupling Constants: The Importance of Non-Fermi-Contact Contributions. J. Chem. Phys. 1994, 101, 2186-2196.

(47) Schäfer, A.; Horn, H.; Ahlrichs, R. Fully Optimized Contracted Gaussian Basis Sets for Atoms Li to Kr. J. Chem. Phys. 1992, 97, 25712577.

(48) Stanton, J. F.; Gauss, J.; Watts, J. D.; Nooijen, M.; Oliphant, N.; Perera, S. A.; Szalay, P. S.; Lauderdale, W. J.; Gwaltney, S. R.; Beck, S.; et al. ACES II; University of Florida: Gainesville, FL, 1991.

(49) Del Bene, J. E.; Alkorta, I.; Sánchez-Sanz, G.; Elguero, J. Structures, Energies, Bonding, and NMR Properties of Pnicogen Complexes $\mathrm{H}_{2} \mathrm{XP}: \mathrm{NXH}_{2}\left(\mathrm{X}=\mathrm{H}, \mathrm{CH}_{3}, \mathrm{NH}_{2}, \mathrm{OH}, \mathrm{F}, \mathrm{Cl}\right)$. J. Phys. Chem. A 2011, 115, 13724-13731.

(50) Koch, U.; Popelier, P. Characterization of C-H-O Hydrogen Bonds on the Basis of the Charge Density. J. Phys. Chem. 1995, 99, 9747-9754.

(51) Del Bene, J. E.; Alkorta, I.; Elguero, J. Do Traditional, Chlorineshared, and Ion-pair Halogen Bonds Exist? An ab Initio Investigation of FCl:CNX Complexes. J. Phys. Chem. A 2010, 114, 12958-12962.

(52) Alkorta, I.; Blanco, F.; Deyá, P. M.; Elguero, J.; Estarellas, C.; Frontera, A.; Quiñonero, D. Cooperativity in Multiple Unusual Weak Bonds. Theor. Chem. Acc. 2010, 126, 1-14.

(53) Alkorta, I.; Sánchez-Sanz, G.; Elguero, J.; Del Bene, J. E. Influence of Hydrogen Bonds on the P...P Pnicogen Bond. J. Chem. Theory Comput. 2012, 8, 2320-2327.

(54) Del Bene, J. E.; Alkorta, I.; Sánchez-Sanz, G.; Elguero, J. Interplay of $\mathrm{F}-\mathrm{H} \cdots \mathrm{F}$ Hydrogen Bonds and P..N Pnicogen Bonds. J. Phys. Chem. A 2012, 116, 9205-9213. 